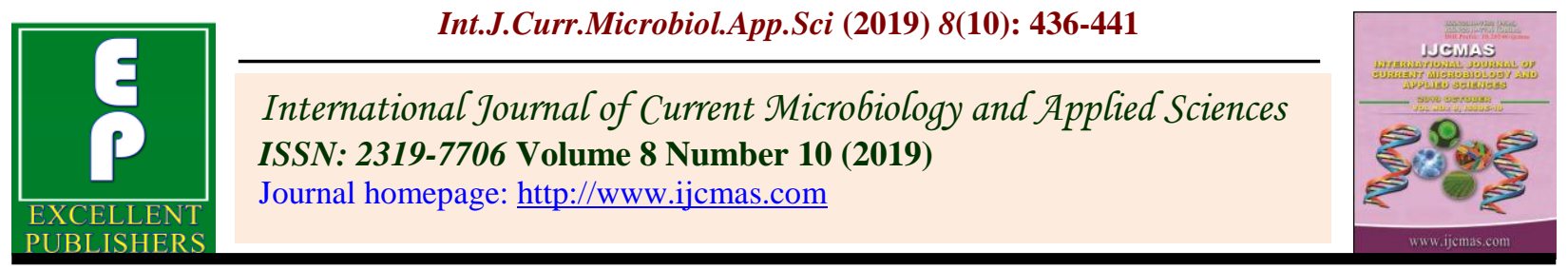

Original Research Article https://doi.org/10.20546/ijcmas.2019.810.046

\title{
Genetic Diversity Profiles of Salmonella typhimurium Isolated from Foods of Animal Origin
}

\author{
Yasarla Suresh*, Chinnam Bindhu kiranmayi, Thummati Srinivasa Rao, \\ M. Srivani and Metta muralidhar
}

Department of Veterinary Publichealth and epidemiology, N.T.R. C.V.Sc, Gannavaram, India

*Corresponding author

\begin{tabular}{|c|}
\hline Keywords \\
\hline $\begin{array}{l}\text { Enterobacteriaceae, } \\
\text { Gram-negative, } \\
\text { Lactose non } \\
\text { fermenting, Rod- } \\
\text { shaped bacteria }\end{array}$ \\
\hline Article Info \\
\hline $\begin{array}{l}\text { Accepted: } \\
\text { 04 September } 2019 \\
\text { Available Online: } \\
10 \text { October } 2019\end{array}$ \\
\hline
\end{tabular}

A B S T R A C T
Salmonella is a foodborne pathogen having a worldwide public health concern. The present study was undertaken to characterize Salmonella typhimurium of animal origin based on cultural isolation and genetic diversity studies by employing ERIC-PCR and REP-PCR. A total of 516 samples comprising poultry cloacal swabs (249), raw foods of animal origin (118 chicken samples, 65 mutton and 30 pork), 17 poultry liver swabs and 37 poultry farm water samples were examined for presence of Salmonella serovars. A total of 21 Salmonella were isolated among them, 7 were S. typhimurium. For all 7 isolates REP and ERIC PCR were employed to study genetic diversity among Salmonella isolates. ERIC PCR and REPPCR analysis revealed a greater degree of heterogeneity among $S$. typhimurium isolates from different sources. ERIC-PCR and REP-PCR genotyping distinguished 7 isolates. The discriminatory power of ERICPCR and REP-PCR for Salmonella typhimurium isolates was found to be highly significant $(>0.9)$ i.e. 1.0 , for both.

\section{Introduction}

Salmonella species is responsible for a wide range of acute and chronic diseases in both poultry and humans. Contaminated poultry products are among the most important sources for foodborne outbreaks in humans. Salmonella is reported more frequently from poultry and poultry products than from any other animal species. Salmonellae are Gramnegative, lactose non fermenting, rod-shaped bacteria belonging to the family Enterobacteriaceae. Salmonella is the most important agent implicated in outbreaks of food-borne diseases around the world (Lacey, 1993). Fuzihara et al., 2000) Typing of bacteria can be used to determine whether isolates recovered from different patients or 
from the environment are related and thus, provide evidence for a common source of transmission of the agent.

Traditional epidemiological methods include biotyping, serotyping and phage typing of isolates, as well as antimicrobial resistance testing, although these methods do not always give enough information for epidemiological purposes. Among the molecular methods for typing bacteria, the REP-PCR, ERIC-PCR and BOX-PCR genomic fingerprinting have been found to be extremely reliable, reproducible, rapid and highly discriminatory (Olivera et al., 2007). ERIC sequences have been used for determining the genetic diversity among different pathogenic bacteria in the Enterobacteriaceae family including Salmonella.

This technique relies on the amplification of genomic DNA fragment using single primer pair, which is complimentary to the short repetitive sequences and generation of reproducible and complex fingerprints (Anjay et al., 2015). The REP-PCR relies on primers that are complementary to the short repetitive sequence elements, dispersed throughout the bacterial genome, to generate DNA fingerprints that allow discrimination between strains (Versalovic et al., 1991).

\section{Materials and methods}

A total of 7 Salmonella typhimurium isolates which were isolated from the different foods of animal origin and one Salmonella typhimurium standard culture (ATCC 14028) was used as standard for ERIC and REP-PCR.

\section{Assessment of genetic diversity}

Assessment of the genetic relatedness among the different Salmonella isolates was done by performing molecular techniques such as ERIC-PCR and REP-PCR.

\section{Genotyping by ERIC-PCR}

S. typhimurium (7) isolates were selected and fingerprinted using ERIC-PCR assay as described by Ye et al., (2011). Genotyping of Salmonella isolates was done using the oligonucleotide primers, ERIC-1 (5'-ATG TAA GCT CCT GGG GAT TCA C-3') and ERIC-2 (5'-AAG TAA GTG ACT GGG GTG AGC G-3') primer pair targeting the amplification of conserved ERIC sequences in the chromosomal DNA of Salmonella isolates, leading to amplicon patterns specific for an individual organism (Versalovic et al., 1991). ERIC-PCR was carried out in $25 \mu$ l optimized reaction mixture under standardized thermal cycling conditions (Table 1). PCR products were subjected to $1.5 \%$ agarose gel electrophoresis and visualized using Gel Documentation unit (BIORAD, USA).

\section{Genotyping by REP-PCR}

S. typhimurium (7) isolates obtained from different sources were subjected to REP-PCR fingerprinting using single oligonucleotide primer (GTG)5 (GTGGTGGTGGTGGTG) as described by Prasertsee et al., (2016) with slight modifications. PCR reactions were optimized in $25 \mu \mathrm{l}$ volume reaction mixture under standardized thermal cycling conditions given in (Table 1). PCR products were subjected to $1.5 \%$ agarose gel electrophoresis and visualized using Gel Documentation unit (BIORAD, USA).

\section{Results and Discussion}

ERIC-PCR typing revealed 2-10 fragments per isolate, ranging in size from $\sim 120$ bp to 2000 bp, whereas REP-PCR typing revealed 4-10 fragments resolved per isolate, ranging in size from $\sim 140$ bp to $\sim 1400$ bp (Figure $1 \& 2$ ).

Of the $7 \mathrm{~S}$. typhimurium analyzed, 6 ERICPCR patterns \& 7 REP patterns were obtained. 
The binary score demonstrating the variety of 6 ERIC (E1-E6) and REP PCR genotypes (R1-R7) were obtained. A pair of $S$. typhimurium isolates (3 and 4 ) that had identical ERIC-PCR pattern (E3) were distinguishable in REP-PCR pattern (R3 \& R4) (Table 2). The two $S$. typhimurium isolates sharing identical ERIC-PCR were recovered from chicken meat samples (C 4 and C 5) of different birds slaughtered in the same chicken retail shop. Dendrograms were constructed based on ERIC and REP-PCR profiles (Fig. 1-3) using dollop program of phylip 3.6 version.

Table.1 Standardized thermal cycling parameters for ERIC and REP-PCR of Salmonella isolates

\begin{tabular}{|l|l|l|l|}
\hline & \multicolumn{2}{|l|}{ Standardized cycling parameters } & \\
\hline Steps & ERIC-PCR & Rep-PCR & No. of cycles \\
\hline $\begin{array}{l}\text { Initial } \\
\text { denaturation }\end{array}$ & $95^{\circ} \mathrm{C}$ for $5 \mathrm{~min}$ & $95^{\circ} \mathrm{C}$ for $5 \mathrm{~min}$ & 1 \\
\hline Denaturation & $94^{\circ} \mathrm{C}$ for $1 \mathrm{~min}$ & $94^{\circ} \mathrm{C}$ for $45 \mathrm{sec}$ & \multirow{2}{*}{40} \\
\hline Annealing & $50^{\circ} \mathrm{C}$ for $1 \mathrm{~min}$ & $40^{\circ} \mathrm{C}$ for $1 \mathrm{~min}$ & \\
\hline Extension & $72^{\circ} \mathrm{C}$ for $2 \mathrm{~min}$ & $65^{\circ} \mathrm{C}$ for $10 \mathrm{~min}$ & \\
\hline Final extension & $72^{\circ} \mathrm{C}$ for $10 \mathrm{~min}$ & $65^{\circ} \mathrm{C}$ for $20 \mathrm{~min}$ & 1 \\
\hline Hold /stand by & $4^{\circ} \mathrm{C}$ for $10 \mathrm{~min}$ & $4^{\circ} \mathrm{C}$ for $10 \mathrm{~min}$ & --- \\
\hline
\end{tabular}

Table.2 Genetic diversity of S. typhimurium from different sources by using ERIC-PCR and REP-PCR

\begin{tabular}{|l|l|l|l|l|}
\hline Species & Biological origin & $\begin{array}{l}\text { Number of } \\
\text { Isolates }\end{array}$ & $\begin{array}{l}\text { Number of } \\
\text { ERIC-types }\end{array}$ & $\begin{array}{l}\text { Number of } \\
\text { REP-types }\end{array}$ \\
\hline \multirow{2}{*}{$\mathbf{n = 7}$} & S. typhimurium \\
& Chicken & 5 & 4 & 5 \\
\cline { 2 - 6 } & Mutton & 1 & 1 & 1 \\
\cline { 2 - 6 } & Pork & 1 & 1 & 1 \\
\hline \multirow{2}{*}{ Total } & & $\mathbf{7}$ & $\mathbf{6}$ & $\mathbf{7}$ \\
\hline
\end{tabular}


Fig.1 Dendogram analysis of ERIC-PCR finger printing od S. typhimurium isolated from different sources.the dendogram was generated by branch and bound method using dollop programm of PHYLIP 3.6 version.

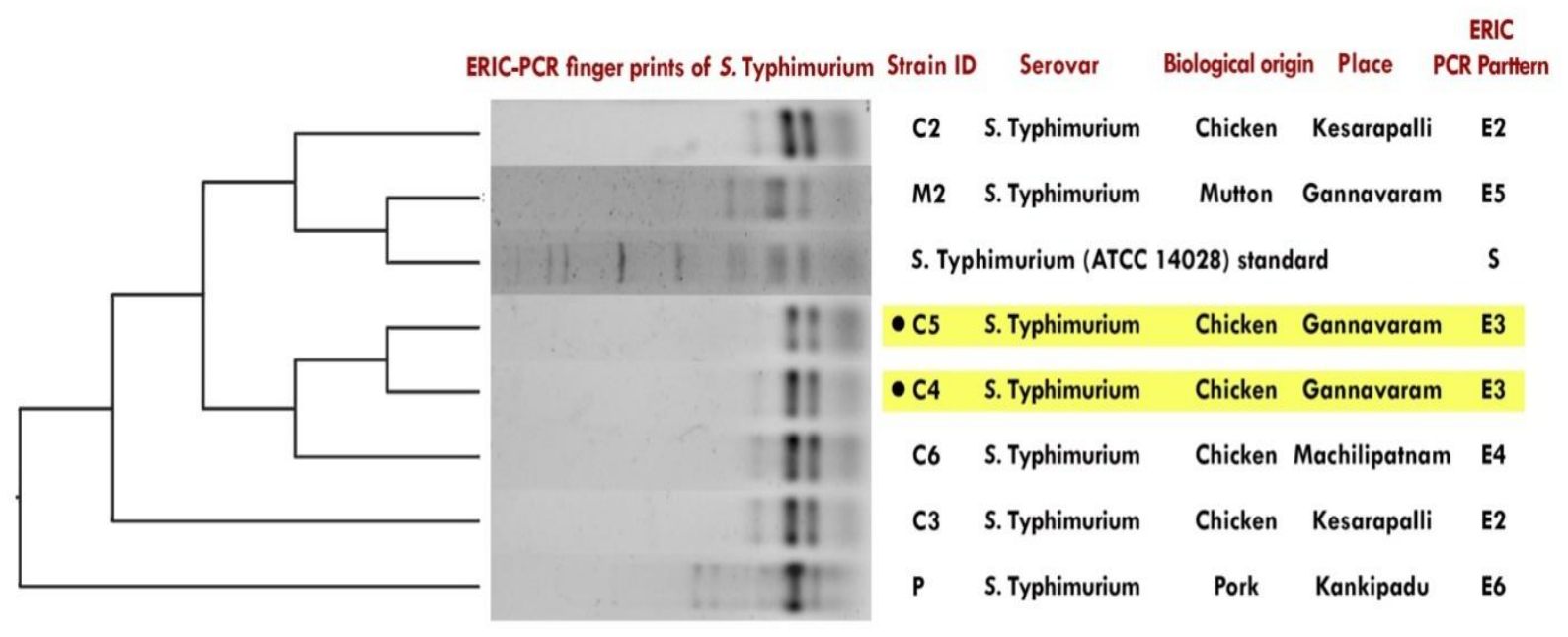

The circle (•) in front of the strain ID indicates strains that had same ERIC-PCR pattern (E3) but had different REP-PCR patterns (R3 and R4)

Fig-26: Dendogram analysis of ERIC-PCR finger printing of $S$. Typhimurium isolated from different sources. The dendogram was generated by 'Branch and Bound method' using dollop program of PHYLIP 3.6 version

Fig.2 Dendogram analysis of REP-PCR finger printing od S. typhimurium isolated from different sources.the dendogram was generated by branch and bound method using dollop programm of PHYLIP 3.6 version

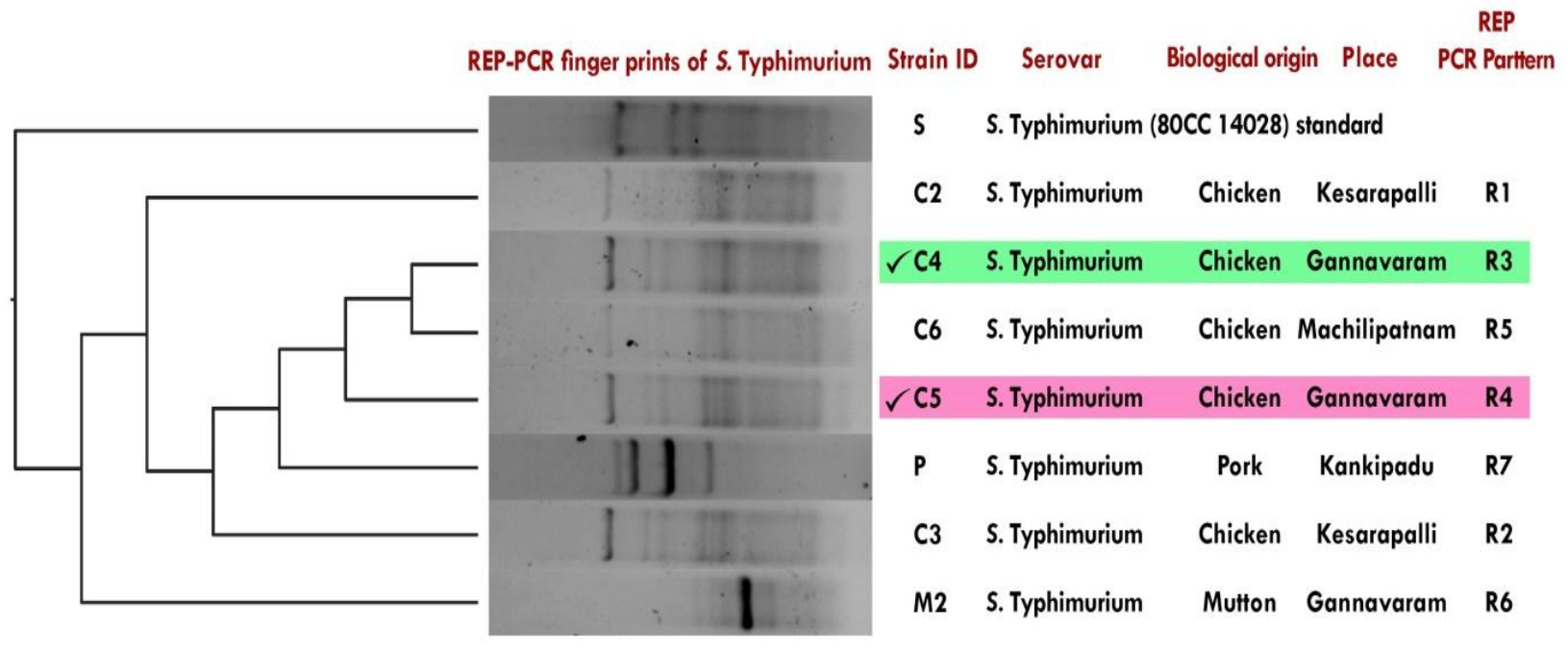

The circle $(\checkmark)$ in front of the strain ID indicates strains that had different REP-PCR patterns (R3 and R4) but had same ERIC-PCR pattern (E3)

Fig-28: Dendogram analysis of REP-PCR finger printing of $S$. Typhimurium isolated from different sources. The dendogram was generated by 'Branch and Bound method' using dollop program of PHYLIP 3.6 version 
Fig.3 Cluster analysis of ERIC-PCR fingerprints of $S$. typhimurium isolates from different sources. An unrooted phylogenetic tree constructed using dollop program of phylip 3.6 version (Branch-and-Bound algorithm)

\section{CLUSTER I}

Isolates recovered from chicken, sub-clustering separately with in cluster

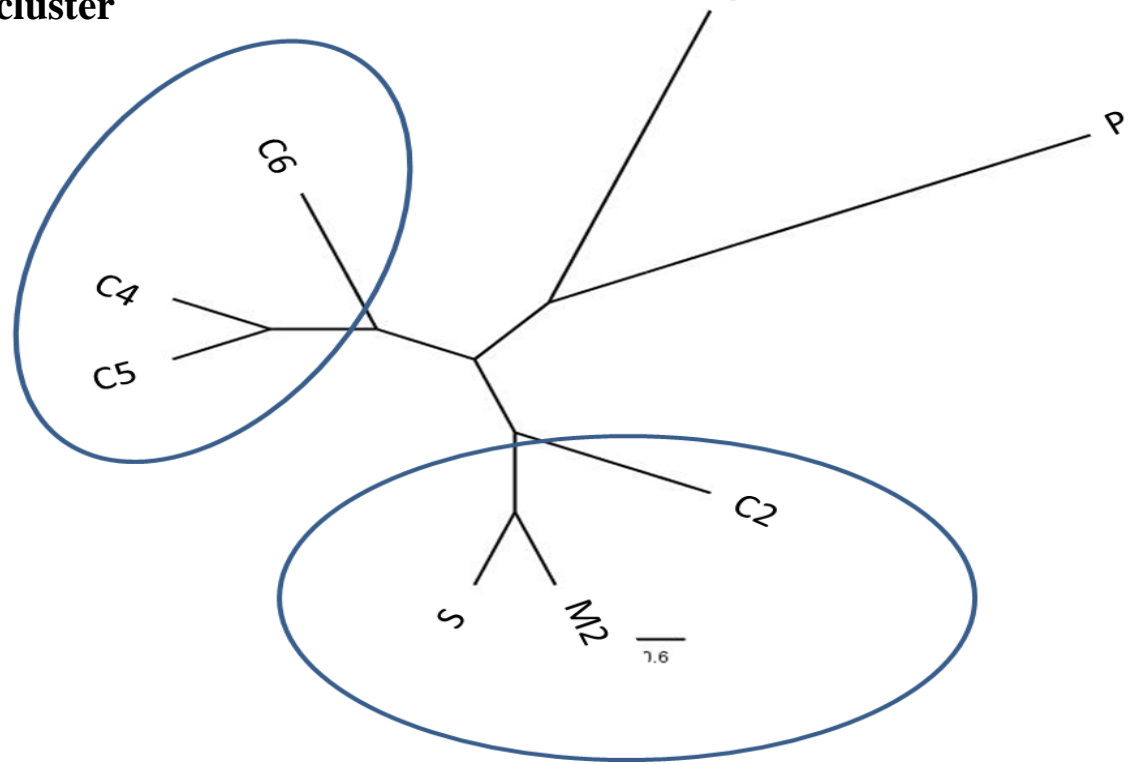

CLUSTER II Isolate from Chicken clustering separately from isolate of mutton and reference standard.

C- Chicken, M- Mutton, S- Salmonella typhimurium ATCC 14028

Fig.4 Cluster analysis of REP-PCR fingerprints of S. typhimurium isolates from different sources. An unrooted phylogenetic tree constructed using dollop program of phylip 3.6 version

(Branch-and-Bound algorithm)

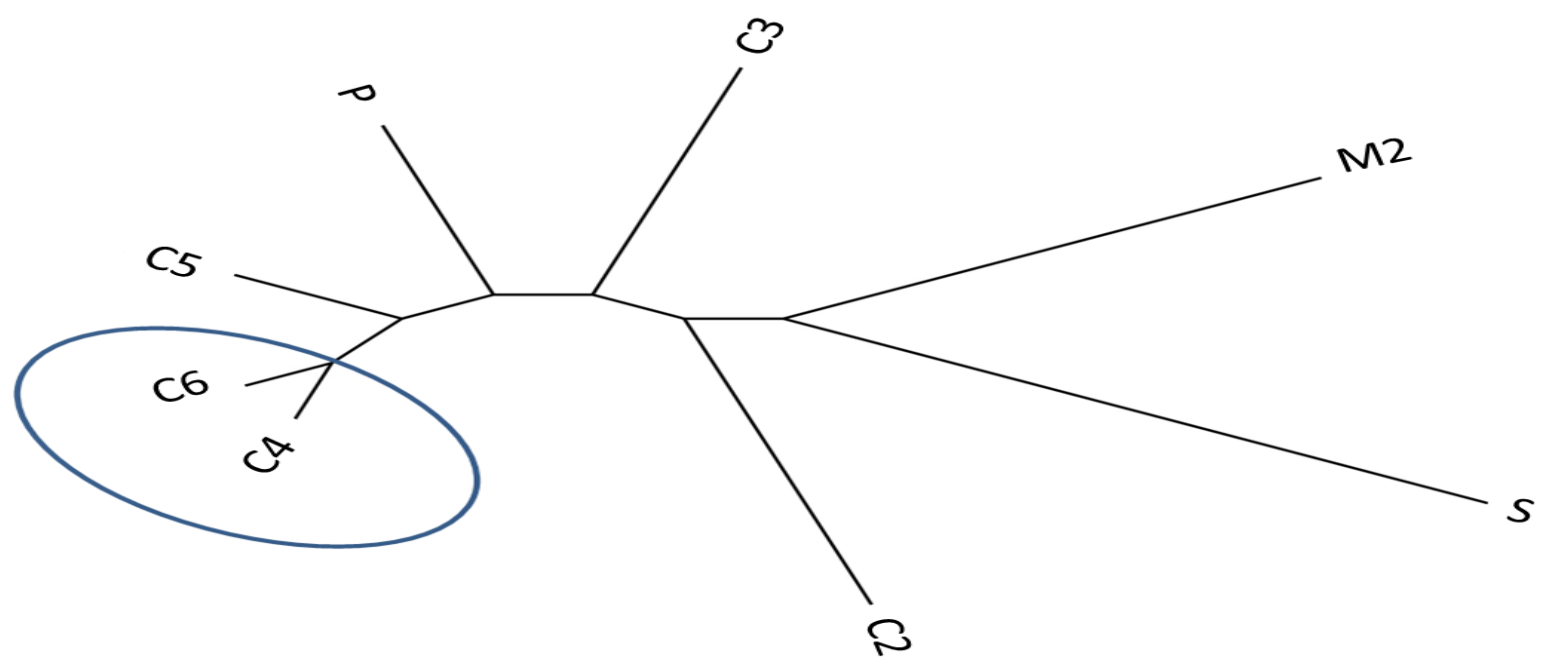

\section{C- Chicken, M- Mutton, S- Salmonella typhimurium ATCC 14028}

Clustering of chicken isolates, $\mathrm{C4}$ and C6 
Dendrogram analysis of ERIC-PCR profiles discriminated $S$. typhimurium isolates into two major clusters (each with three isolates) i.e. CL1 (C6, C5, C4) and CL 2 (C2, M2 and reference standard $S$. typhimurium ATCC 14028) for a $70 \%$ similarity cut-off. Two isolates $(\mathrm{C} 3, \mathrm{P})$ were found to be unclustered (UC) with other isolates. Within the cluster CL1, isolate C6 clustered separately from that of other two isolates (C5, C4). Within the cluster CL2, isolate C2 clustered separately from that of other two isolates (M2 and reference standard) (Figure-3). Cluster analysis indicated wide genetic diversity among the isolates.

Dendrogram analysis of REP-PCR profiles discriminated $S$. typhimurium isolates into a major cluster with two isolates $(\mathrm{C} 4, \mathrm{C} 6)$ for a $70 \%$ similarity cut-off, while the other five isolates along with the reference standard were found to be unclustered (UC) with other isolates Figure 4). Cluster analysis indicated wide genetic diversity among the isolates.

\section{Acknowledgement}

The authors thank Sri Venkateswara Veterinary University, Tirupati, Andhra Pradesh, for providing necessary facilities and funds to carry out the work.

\section{References}

Anjay, Kumar, A., Agarwal, R. K., Ramees,
T. P., Dubal, Z. B., Kaushik, P., Kumar, M. S., Dudhe, N. C., Milton, A. A. P., Abhishek., Kumar, B. and Bi, S. 2015. Molecular Typing of Salmonella typhimurium and $S$. enteritidis serovar from Diverse Origin by ERIC-PCR. 9(3): 2627-2634.

Fuzihara, T. O., Fernandes, S. A. and Franco, B. D. 2000. Prevalence and dissemination of Salmonella serotypes along the slaughtering process in Brazilian small poultry slaughterhouses. J. Food Prot.63: 1749-1753.

Oliveira, S. D., Bessa, M. C., Santos, L. R., Cardoso, M. R. D., Brandelli, A. and Canal., C. W. 2007. Phenotypic and genotypic characterization of Salmonella enteritidis isolates. Brazilian Journal of Microbiology. 38:720-728.

Versalovic, J., Koeuth, T. and Lupski, J. R. 1991. Distribution of repetitive DNA sequences in eubacteria and application to fingerprinting of bacterial genomes. Nucleic Acids Res. 19: 6823-6831.

Ye, Y., Wu, Q., Zhang, J., Lu, J. and Lin, L. 2011. Isolation of Salmonella from meat samples and characterization by Enterobacterial repetitive intergenic consensus-Polymerase Chain Reaction and antibiotics test. Foodborne Pathogens and Disease. 8(8): 935-7.

\section{How to cite this article:}

Yasarla Suresh, Chinnam Bindhu kiranmayi, Thummati Srinivasa Rao, M. Srivani and Metta Muralidhar. 2019. Genetic Diversity Profiles of Salmonella typhimurium Isolated from Foods of Animal Origin. Int.J.Curr.Microbiol.App.Sci. 8(10): 436-441. doi: https://doi.org/10.20546/ijcmas.2019.810.046 